Research Article

\title{
Effect of Different Management Strategies on Melon Fruit Fly, Bactrocera cucurbitae (Coquillett), Infestation in Cucurbit Vegetables
}

\author{
Muhammad Ibrahim Kubar ${ }^{1}$, Fahad Nazir Khoso ${ }^{1 *}$, Imran Khatri ${ }^{1}$, Niaz Hussain Khuhro ${ }^{2}$ and Arfan \\ Ahmed Gilal ${ }^{1}$
}

${ }^{1}$ Department of Entomology, Sindh Agriculture University, Tandojam, Sindh, Pakistan; ${ }^{2}$ Nuclear Institute of Agriculture, Tandojam, Sindh, Pakistan.

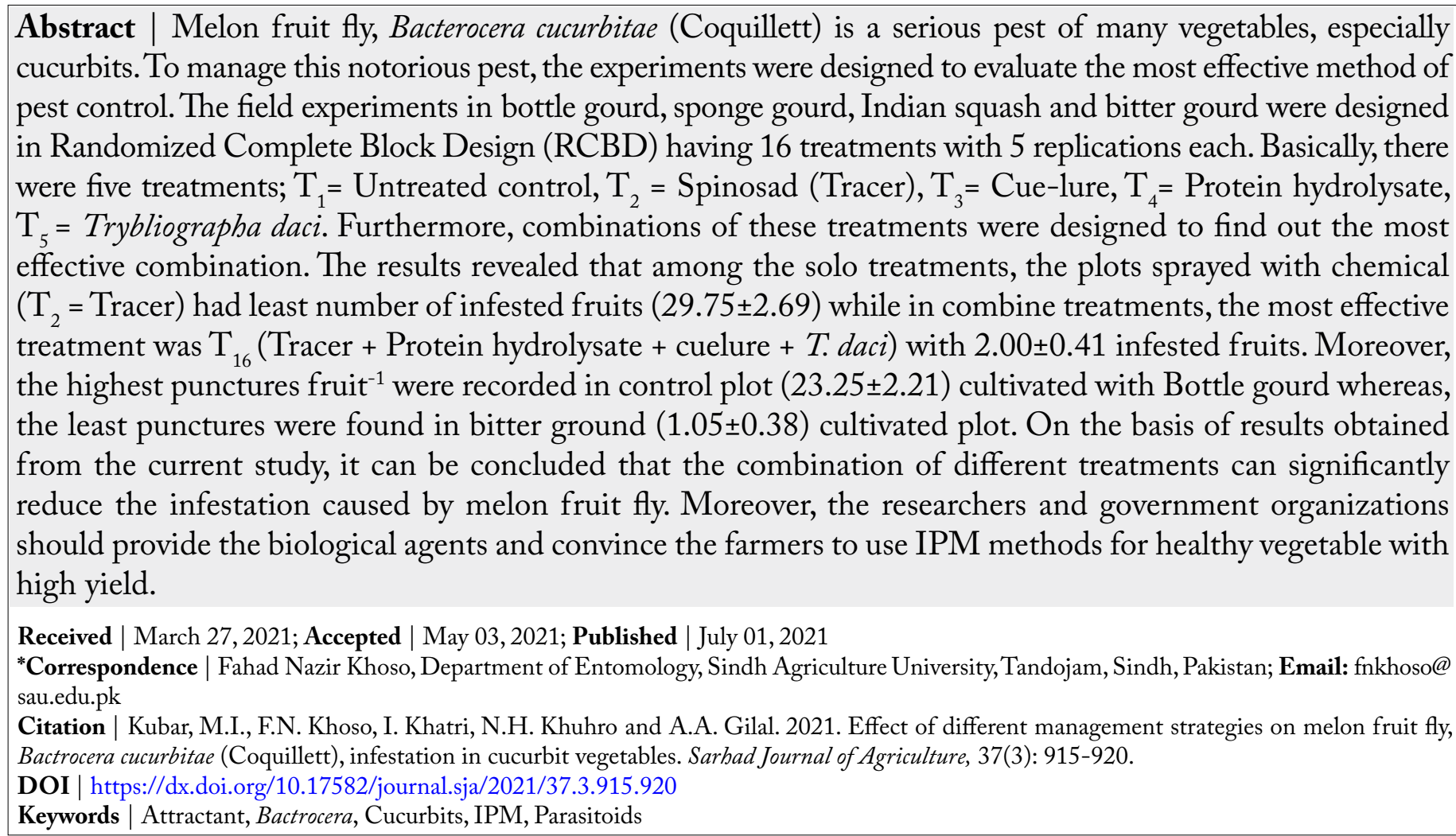

\section{Introduction}

$\mathrm{T}$ he vegetables belonging to family cucurbitae have great importance and considered as one of the largest group of vegetables cultivated throughout the world in humid as well as tropic environments (Nath, 2007). Most of these cucubit vegetables are extensively cultivated for their edible fruits with higher nutritional values and long shelf life. Moreover, flowers and leaves have ornament values and cultivated for aesthetic attraction (Weinberger and Genova, 2005). These vegetables are enriched with protein, vitamins and minerals that are basic components of nutrition and essential for human health (Slavin and Lloyd, 2012).

The farmers are facing many difficulties in cultivating these vegetables due to disease and insect pests. The fruit flies are one of the most notorious and problematic pests. The fruit flies (Diptera: Tephritidae) are not only 
harmful for fruits but they also cause serious damage to vegetables and other crops in different regions of the world (Demeyer et al., 2010). The member of family tephritidae is the most commonly appearing insect pests in cucurbits. One of these, melon fruit fly (Bactrocera cucurbitae Coquillett) is distributed throughout the world. It is a noxious pest of a variety of vegetables especially family cucurbitaceae (Bharathi et al., 2004). In vegetable crops, B. cucurbiate can cause $30-100 \%$ yield losses (Dhillon et al., 2005). It not only cause direct damage to the yield and marketability of fruits and vegetables, but they also pose as significant threats to quarantine security that results in hurdles to international trade in fruits and fresh vegetables world-wide (Joomaye, 2000). The damage percentage or infestation of B. cucurbitae varies from host to host and the environmental condition of the area (Muhammad et al., 2007).

The damage starts with the appearance of larvae from the eggs laid by the female adult fly just below the upper epidermis or sometime little deeper in the pulp of the fruit (Shang et al., 2014). The visit of the B. cucurbitae golden colored flies is the sign of infestation started in the field (Weems and Heppner, 2004). Females oviposit eggs by puncturing the fruit that result in excretion of fluid that accumulates on the surface. Later on, the droplets appears like brown resinous deposit and dark spots on the surface are the visible symptoms. These symptoms are the clear indication of larval presence inside the fruit (Hafiz et al., 2020). The maggots cause damage by making tunnels inside the fruit, the pulp becomes soft and contaminated with frass due to feeding of larvae that support the development of pathogenic infection (Abro et al., 2017b). The infested fruit become deformed, rotten or losses fluid which makes it hard and unfit for human consumption (Dhillon et al., 2005). Several management options have been adopted against to minimize the pest infestation. The most promising strategies are application of protein hydrolysate spray, field sanitation, installation of pheromone trap, cue-lure trap, spraying of botanical extracts (ailanthus, cashew leaf extract, neem products), bagging of fruits, food baits and spray of chemical insecticides (Akhtaruzzaman et al., 2000). It is always very hazardous to control pest population only through pesticides because indiscriminate use of chemical insecticides has increased resistance of noxious fruit flies, heavy resurgence to infestation by some insect species because of the destruction of natural enemies i.e., predators and parasitoids (Sarwar et al., 2013). Therefore, developing an insect pest management program for a specific agro-ecosystem, it is necessary to gather basic information and firsthand knowledge on the incidence of the pest in relation to appropriate time of action and suitable methods of control. Monitoring pest population round the year is one of the most important and basic information in formulating an IPM program for sustainable $B$. cucurbitae management. The use of lure for male fruit flies and food attractants for female fruit flies has suggested for male and female attractants (Mahmood et al., 2002). Therefore, this study focused on the combination of various control techniques to manage the population of $B$. cucurbitae in various cucurbit vegetables to get healthy fruits with better yields.

\section{Materials and Methods}

\section{Experimental site}

Experimental field, Nuclear Institute of Agriculture, Tandojam (NIA), District Hyderabad.

\section{Cultivation of vegetables}

The seeds of cucurbit vegetables i.e. bottle gourd (var. Digho), sponge gourd (var. Geeha), Indian squash (var. Achho) and bitter gourd (var. Nasarpuri) was obtained from Sindh Horticulture Research Institute (SHRI), Mirpurkhas. The sowing was done during $1^{\text {st }}$ week of March, 2016 on the ridges prepared with the help of ridger. Plant spacing (hill $\mathrm{x}$ ridge) of 0.5 x $2 \mathrm{~m}$ was maintained in all vegetables. Total sixteen treatments as mentioned below were arranged in a Randomized Complete Block Design (RCBD), where each treatment was replicated five times; thus, size of each experimental plot was $195 \times 195 \mathrm{~m}$. All the recommended cultural practices viz. irrigation, fertilization, weeding was applied to all vegetables as per recommendations of SHRI, Mirpurkhas.

\section{Treatments}

Basically, there were five treatments: $T_{1}=$ Untreated control, $\mathrm{T}_{2}=$ Chemical Spinosad (Tracer) $0.4 \mathrm{ml} /$ Litre) organophosphours group (Manufacturer Dow Agro Sciences, USA), $\mathrm{T}_{3}=$ Cue-lure $4 \mathrm{ml}(95 \%+5 \%)$ [cue-lure (4-p- acetoxyphenyl 2-butanone) and Tracer treated cotton wool wick, recharged at 15 days interval (Shanghai Kayi Chemicals Co. Ltd.), $\mathrm{T}_{4}=$ Proteinhydrolysate $200 \mathrm{ml} /$ Litre (Hangzhou Lingeba Technology Co. Ltd). $\mathrm{T}_{5}=$ T.daci (Bio-control agent) (30,000/acre and release 5000/cage every fortnightly provided by fruit fly and Parasitoids laboratory NIA 
Tandojam. Further, these five treatements were combined to make combinations to make the modules, as given below, to find out the best combination to control the fruit flies.

$\mathrm{T}_{1}=$ Untreated control, $\mathrm{T}_{2}=$ Spinosad (Tracer), $\mathrm{T}_{3}=$ Cue-lure, $\mathrm{T}_{4}=$ Protein hydrolysate, $\mathrm{T}_{5}=$ Trybliographa daci, $\mathrm{T}_{6}=$ Tracer + Cue-lure, $\mathrm{T}_{7}=$ Tracer + Protein hydrolysate, $\mathrm{T}_{8}=$ Tracer $+T$. daci, $\mathrm{T}_{9}=$ Cue-lure + Protein hydrolysate, $\mathrm{T}_{10}=$ Cue-lure $+T$. daci, $\mathrm{T}_{11}=$ Protein hydrolysate $+T$. daci, $\mathrm{T}_{12}=$ Tracer + cue-lure + Protein hydrolysate, $\mathrm{T}_{13}=$ Tracer + cue-lure $+T$. daci, $\mathrm{T}_{14}=$ Cue-lure + Protein hydrolysate $+T$. daci, $\mathrm{T}_{15}=$ Tracer + Protein hydrolysate $+T$. daci, $\mathrm{T}_{16}=$ Tracer + Protein hydrolysate + cue-lure $+T$. daci

\section{Observations recorded}

Total sixty fruits were randomly selected from each treated plot (twenty fruits per picking) to record following parameters: (1) Number of infested fruits plant $^{-1} ;(2)$ Number of punctures fruit ${ }^{-1}$

\section{Statistical analysis}

The collected data was subjected to statistical analysis using STATIX 8.1 computer software (Statix, 2006). Two-way Analysis of Variance was used to determine the effect of various management practices on the population reduction of $B$. cucurbitae on the studied four cucurbit vegetables. Moreover, means with significant differences were separated using the Least Square Difference (LSD).

\section{Results and Discussion}

\section{Infested fruits and punctures fruit ${ }^{-1}$}

Efficacy of combined control methods were tested on number of fruit infestation on cucurbit vegetables. The data shown in Table 1 revealed that number of fruit infestation varied significantly among different treatments $(\mathrm{F}=1.52, \mathrm{P}=<0.05)$. The highest reduction in fruit infestation was recorded in fruits collected from plot treated with $\mathrm{M}_{16}$. The mean infestation number of punctures/ fruit was $3.00 \pm 0.41,4.00 \pm 0.91$ and $6.00 \pm 0.91$ on bitter gourd, Indian squash, sponge gourd and bottle gourd, respectively. After application of $\mathrm{T}_{16}$, the least mean infestation was observed on plots treated with $\mathrm{M}_{12}$ treatment that has statistical data $2.44 \pm 0.58$ for bitter gourd, $3.13 \pm 0.83$ for Indian squash, $4.63 \pm 0.85$ for sponge gourd, and $6.88 \pm 1.16 \%$ for bottle gourd. Moreover, the highest infested fruits i.e.,
$49.25 \pm 2.32,41.00 \pm 2.27,39.50 \pm 2.25$ and $37.00 \pm 1.83 \%$ were observed on bottle gourd, sponge gourd, Indian squash and bitter gourd, respectively when $T_{1}$ was used, followed by $\mathrm{T}_{5}$ as $38.00 \pm 2.74,36.25 \pm 2.46$, $35.00 \pm 2.72$ and $34.25 \pm 2.87 \%$ infestation was observed on bottle gourd, sponge gourd, Indian squash and bitter gourd, respectively. Results regarding number punctured fruits are given in Table 2. According to observations, $\mathrm{T}_{16}$ was significantly more effective as there were lowest number of punctured fruits were recorded on bitter gourd $(1.05 \pm 0.38)$, Indian squash $(1.88 \pm 0.39)$, sponge gourd $(2.00 \pm 0.94)$, and bottle gourd $(2.10 \pm 1.08)$, followed by $\mathrm{T}_{12}$ with $1.06 \pm 0.41$, $2.38 \pm 1.03,2.95 \pm 1.07$, and $3.75 \pm 1.13$, bitter gourd, Indian squash, sponge gourd and bottle gourd, respectively on above mentioned cucurbit vegetables. However, the highest punctured fruits $23.25 \pm 2.21$, $20.38 \pm 2.11,18.70 \pm 2.1$ and $17.69 \pm 1.6$, observed on bottle gourd, sponge gourd, Indian squash and bitter gourd, respectively were recorded in $\mathrm{T}_{1}$, followed by $\mathrm{M}_{5}$ where $12.62 \pm 1.25,9.83 \pm 1.48,11.22 \pm 1.57$, $8.45 \pm 0.91$ punctures were observed on bottle gourd, sponge gourd, Indian squash and bitter gourd, respectively.

Various studies have highlighted the significance of various management practices in reducing the damage percentage of $B$. cucurbitae in different cucurbit vegetables (Khatiwada and Pokhrel, 2004; Weems and Heppner, 2004). Abro et al. (2017a) also found that in comparison to control, application of protein hydrolysate on various cucurbits suffered lowest losses of $B$. cucurbitae, followed by $\mathrm{Nu}$-lure. Similarly, in our study, protein hydrolysate was also a key component that may have played a significant role in reduction of $B$. cucurbitae on cucurbit vegetables used. Studies also highlighted that comparatively higher attraction of $B$. cucurbitae has been recorded to various attractants i.e., cue-lure and methyl euginol when they were used in same trap, in comparison to their individual application (Uzair and Unab, 2016). Vargas et al. (2000) observed that lures i.e., methyl eugenol and cue-lure are highly attractive lures for fruit flies, however cue-lure was the best attractant lure for B. cucurbitae while methyl eugenol was the best attractive for $B$. dorsalis. Same as in present studies cue-lure was observed to be the most important attractant lure for attraction of adult male flies. Moreover, the reason behind using the T. daci was that it is found in the vicinity of experimental area (Tandojam) and also reared in the laboratory 
Table 1: Infested cucurbit vegetables after application of different treatments.

\section{Treatmets}

$\mathrm{T}_{1}=$ Control

$\mathrm{T}_{2}=$ Tracer

$\mathrm{T}_{3}=$ Cuelure

$\mathrm{T}_{4}=$ Protein hydrolsate

$\mathrm{T}_{5}=$ T. daci

$\mathrm{T}_{6}=$ Tracer + Cuelure

$\mathrm{T}_{7}=$ Tracer + Protein hydrolysate

$\mathrm{T}_{8}=$ Tracer $+T$. daci

$\mathrm{T}_{9}=$ Cuelure + Protein hydrolysate

$\mathrm{T}_{10}=$ Cuelure $+T$. daci

$\mathrm{T}_{11}=$ Protein hydrolysate $+T$. daci

$\mathrm{T}_{12}=$ Tracer + Cuelure + Protein hydrolysate

$\mathrm{T}_{13}=$ Tracer + Cuelure $+T$. daci

$\mathrm{T}_{14}=$ Cuelure+Protein hydrolysate $+T$. daci

$\mathrm{T}_{15}=$ Tracer + Protein hydrolysate $+T$. daci

$\mathrm{T}_{16}=$ Tracer + Protein hydrolysate + Cuelure $+T$. daci

LSD@0.05=4.90; $P$ value $=0.02$

\section{Vegetables}

$\begin{array}{llll}\text { Bottle gourd } & \text { Sponge gourd } & \text { Indian squash } & \text { Bitter gourd } \\ 49.25 \pm 2.32^{\mathrm{a}} & 41.00 \pm 2.27^{\mathrm{b}} & 39.50 \pm 2.25^{\mathrm{bc}} & 37.00 \pm 1.83^{\mathrm{b}-\mathrm{e}} \\ 33.00 \pm 2.27^{\mathrm{e}-\mathrm{j}} & 32.75 \pm 2.29^{\mathrm{e}-\mathrm{j}} & 31.75 \pm 2.10^{\mathrm{f}-\mathrm{j}} & 29.75 \pm 2.69^{\mathrm{ij}} \\ 34.25 \pm 2.29^{\mathrm{d}-\mathrm{i}} & 33.75 \pm 2.29^{\mathrm{d}-\mathrm{i}} & 32.75 \pm 2.10^{\mathrm{e}-\mathrm{j}} & 30.75 \pm 2.69^{\mathrm{g}-\mathrm{j}} \\ 35.00 \pm 2.35^{\mathrm{c}-\mathrm{g}} & 34.75 \pm 2.10^{\mathrm{c}-\mathrm{h}} & 33.75 \pm 2.39^{\mathrm{d}-\mathrm{i}} & 31.00 \pm 2.48^{\mathrm{g}-\mathrm{j}} \\ 38.00 \pm 2.74^{\mathrm{bcd}} & 36.25 \pm 2.46^{\mathrm{b}-\mathrm{f}} & 35.00 \pm 2.72^{\mathrm{c}-\mathrm{g}} & 34.25 \pm 2.87^{\mathrm{d}-\mathrm{i}} \\ 20.50 \pm 1.04^{1-\mathrm{p}} & 16.50 \pm 1.04^{\mathrm{p}-\mathrm{s}} & 14.75 \pm 1.38^{\mathrm{q}-\mathrm{u}} & 10.00 \pm 1.08^{\mathrm{u}-\mathrm{x}} \\ 21.50 \pm 1.04^{1-\mathrm{o}} & 17.50 \pm 1.04^{\mathrm{o}-\mathrm{r}} & 15.75 \pm 1.38^{\mathrm{p}-\mathrm{t}} & 11.00 \pm 1.08^{\mathrm{t}-\mathrm{w}} \\ 30.00 \pm 2.48^{\mathrm{hij}} & 23.75 \pm 2.56^{\mathrm{klm}} & 18.75 \pm 1.93^{\mathrm{n}-\mathrm{q}} & 16.50 \pm 1.94^{\mathrm{p}-\mathrm{s}} \\ 31.00 \pm 2.89^{\mathrm{g}-\mathrm{j}} & 24.00 \pm 1.68^{\mathrm{kl}} & 22.50 \pm 1.71^{1 \mathrm{mn}} & 17.50 \pm 1.94^{\mathrm{o}-\mathrm{r}} \\ 29.75 \pm 2.14^{\mathrm{ij}} & 22.50 \pm 1.85^{\mathrm{lmn}} & 19.00 \pm 1.41^{\mathrm{m}-\mathrm{q}} & 14.50 \pm 1.85^{\mathrm{q}-\mathrm{u}} \\ 28.50 \pm 1.19^{\mathrm{jk}} & 24.75 \pm 1.38^{\mathrm{kl}} & 18.50 \pm 1.85^{\mathrm{n}-\mathrm{q}} & 13.50 \pm 1.55^{\mathrm{r}-\mathrm{v}} \\ 6.88 \pm 1.16^{\mathrm{w}-\mathrm{C}} & 4.63 \pm 0.85^{\mathrm{y}-\mathrm{C}} & 3.13 \pm 0.83^{\mathrm{ABC}} & 2.44 \pm 0.58^{\mathrm{BC}} \\ 20.00 \pm 1.47^{1-\mathrm{p}} & 15.75 \pm 1.38^{\mathrm{p}-\mathrm{t}} & 11.75 \pm 1.93^{\mathrm{s}-\mathrm{w}} & 7.50 \pm 0.65^{\mathrm{w}-\mathrm{A}} \\ 15.00 \pm 1.08^{\mathrm{q}-\mathrm{t}} & 11.25 \pm 0.48^{\mathrm{t}-\mathrm{w}} & 9.00 \pm 0.71^{\mathrm{v}-\mathrm{y}} & 7.00 \pm 0.91^{\mathrm{w}-\mathrm{B}} \\ 11.25 \pm 1.38^{\mathrm{t}-\mathrm{w}} & 11.25 \pm 1.11^{\mathrm{t}-\mathrm{w}} & 11.00 \pm 1.58^{\mathrm{t}-\mathrm{w}} & 8.25 \pm 1.11^{\mathrm{w}-\mathrm{z}} \\ 6.00 \pm 0.91^{\mathrm{x}-\mathrm{C}} & 4.00 \pm 0.91^{\mathrm{z}-\mathrm{C}} & 3.00 \pm 0.41^{\mathrm{ABC}} & 2.00 \pm 0.41^{\mathrm{C}}\end{array}$

Table 2: Punctures fruit ${ }^{-1}$ of cucurbit vegetables after application of different treatments.

\section{Methods}

$\mathrm{T}_{1}=$ Control

$\mathrm{T}_{2}=$ Tracer

$\mathrm{T}_{3}=$ Cuelure

$\mathrm{T}_{4}=$ Protein hydrolsate

$\mathrm{T}_{5}=T$. daci

$\mathrm{T}_{6}=$ Tracer + Cuelure

$\mathrm{T}_{7}=$ Tracer + Protein hydrolysate

$\mathrm{T}_{8}=$ Tracer $+T$. daci

$\mathrm{T}_{9}=$ Cuelure + Protein hydrolysate

$\mathrm{T}_{10}=$ Cuelure $+T$. daci

$\mathrm{T}_{11}=$ Protein hydrolysate $+T$. daci

$\mathrm{T}_{12}=$ Tracer + Cuelure + Protein hydrolysate

$\mathrm{T}_{13}=$ Tracer + Cuelure $+T$. daci

$\mathrm{T}_{14}=$ Cuelure+Protein hydrolysate $+T$. daci

$\mathrm{T}_{15}=$ Tracer + Protein hydrolysate $+T$. daci

$\mathrm{T}_{16}=$ Tracer + Protein hydrolysate + Cuelure $+T$. daci

LSD@0.05=3.8; P value $=0.03$

\section{Vegeta bles}

$\begin{array}{llll}\text { Bottle gourd } & \text { Sponge gourd } & \text { Indian squash } & \text { Bitter gourd } \\ 23.25 \pm 2.21^{\mathrm{a}} & 20.38 \pm 2.11^{\mathrm{ab}} & 18.70 \pm 2.17^{\mathrm{b}} & 17.69 \pm 1.63^{\mathrm{b}} \\ 11.02 \pm 1.01^{\mathrm{c}-\mathrm{i}} & 9.06 \pm 1.46^{\mathrm{d}-\mathrm{n}} & 7.59 \pm 1.69^{\mathrm{g}-\mathrm{r}} & 6.40 \pm 1.20^{1-\mathrm{u}} \\ 13.00 \pm 1.08^{\mathrm{c}} & 11.00 \pm 1.27^{\mathrm{c}-\mathrm{i}} & 8.00 \pm 1.08^{\mathrm{f}-\mathrm{o}} & 7.00 \pm 1.10^{\mathrm{j}-\mathrm{s}} \\ 11.99 \pm 1.29^{\mathrm{cde}} & 11.38 \pm 1.43^{\mathrm{c}-\mathrm{g}} & 9.55 \pm 1.20^{\mathrm{c}-\mathrm{m}} & 8.38 \pm 1.03^{\mathrm{e}-\mathrm{o}} \\ 12.62 \pm 1.25^{\mathrm{cd}} & 11.22 \pm 1.57^{\mathrm{c}-\mathrm{h}} & 9.83 \pm 1.48^{\mathrm{c}-\mathrm{l}} & 8.45 \pm 0.91^{\mathrm{e}-\mathrm{o}} \\ 10.10 \pm 1.05^{\mathrm{c}-\mathrm{l}} & 8.14 \pm 1.71^{\mathrm{e}-\mathrm{o}} & 7.06 \pm 1.70^{\mathrm{j}-\mathrm{s}} & 5.71 \pm 1.17^{\mathrm{m}-\mathrm{w}} \\ 10.48 \pm 1.15^{\mathrm{c}-\mathrm{k}} & 9.28 \pm 1.82^{\mathrm{c}-\mathrm{n}} & 8.57 \pm 2.35^{\mathrm{e}-\mathrm{o}} & 8.14 \pm 1.55^{\mathrm{e}-\mathrm{o}} \\ 11.13 \pm 1.20^{\mathrm{c}-\mathrm{h}} & 9.41 \pm 1.47^{\mathrm{c}-\mathrm{m}} & 7.22 \pm 2.10^{\mathrm{i}-\mathrm{r}} & 6.85 \pm 1.24^{\mathrm{j}-\mathrm{s}} \\ 10.63 \pm 1.43^{\mathrm{c}-\mathrm{j}} & 8.72 \pm 2.15^{\mathrm{e}-\mathrm{o}} & 7.34 \pm 1.89^{\mathrm{h}-\mathrm{r}} & 6.46 \pm 1.75^{1-\mathrm{u}} \\ 11.52 \pm 1.51^{\mathrm{c}-\mathrm{f}} & 9.25 \pm 1.38^{\mathrm{c}-\mathrm{n}} & 7.75 \pm 1.25^{\mathrm{f}-\mathrm{p}} & 7.70 \pm 2.28^{\mathrm{f}-\mathrm{q}} \\ 11.13 \pm 1.01^{\mathrm{c}-\mathrm{h}} & 9.02 \pm 1.93^{\mathrm{d}-\mathrm{n}} & 8.11 \pm 1.78^{\mathrm{e}-\mathrm{o}} & 6.71 \pm 1.27^{\mathrm{k}-\mathrm{t}} \\ 3.75 \pm 1.13^{\mathrm{r}-\mathrm{x}} & 2.95 \pm 1.07^{\mathrm{t}-\mathrm{x}} & 2.38 \pm 1.03^{\mathrm{vwx}} & 1.06 \pm 0.41^{\mathrm{x}} \\ 9.13 \pm 1.20^{\mathrm{c}-\mathrm{n}} & 6.73 \pm 0.83^{\mathrm{k}-\mathrm{t}} & 4.86 \pm 1.48^{\mathrm{o}-\mathrm{x}} & 3.25 \pm 0.85^{\mathrm{s}-\mathrm{x}} \\ 7.80 \pm 1.08^{\mathrm{f}-\mathrm{p}} & 5.88 \pm 1.43^{\mathrm{m}-\mathrm{v}} & 3.95 \pm 1.04^{\mathrm{p}-\mathrm{x}} & 2.75 \pm 0.83^{\mathrm{u}-\mathrm{x}} \\ 7.95 \pm 1.20^{\mathrm{f}-\mathrm{o}} & 5.50 \pm 1.19^{\mathrm{n}-\mathrm{w}} & 3.83 \pm 0.78^{\mathrm{q}-\mathrm{x}} & 2.38 \pm 0.24^{\mathrm{vwx}} \\ 2.10 \pm 1.08^{\mathrm{vwx}} & 2.00 \pm 0.94^{\mathrm{vwx}} & 1.88 \pm 0.39^{\mathrm{wx}} & 1.05 \pm 0.38^{\mathrm{x}}\end{array}$

established in NIA. Previously, T. daci is also reported to be associated with the fruit flies in mango orchard (Shah et al., 2014). The results of this study are in line with the studies conducted by Papadopouls and Katsoyanos (2003) and Andleeb et al. (2010) which conclude that fruits punctures on fruits in plot where
T. daci were released had less number of punctures/ fruit when compared with control plots.

Moreover, in different parts of the world various researchers worked on the different IPM strategies against $B$. cucurbitae depending on the availability 
of local resources. The recent work by Kumari et al. (2021) on bitter gourd, proved that integration of seed treatment with thiamethoxam 70 WS 5-10 g/ $\mathrm{kg}$ seed, removal of cotyledonary leaves 7 days after germination, spraying Emamectin benzoate $25 \mathrm{WG}$ @ $0.4 \mathrm{~g} / 1$, spraying- /Neem oil 3000 ppm @ 5 ml/1, Installation of cuelure traps 15/acre and spraying spinosad 45 SC@0 $0.3 \mathrm{ml} / 1$ caused the least infestation in the bitter gourd fruit. Similarly, the implementation of IPM modules in bitter gourd and muskmelon minimized the fruit infestation (Haldhar et al., 2014; Sarkar et al., 2017). The observation of this particular study is also in agreement with published literature that the integration of different control measured can reduce the infestation and damage significantly as compared to conventional methods.

\section{Conclusions and Recommendations}

Integrations of $\mathrm{T}_{16}$ comprised of Tracer + Protein hydrolysate + cue-lure + T.daci was found comparatively more effective in reducing the infestation of $B$. cucurbitae on all four vegetables, hence, suggested for the management of B. cucurbitae.

\section{Acknowledgements}

The authors are highly thankful to Nuclear Institute of Agriculture (NIA) Tandojam for providing necessary material and facilities to conduct the experiments.

\section{Novelty Statement}

The present research work investigated the management of $B$. cucurbitae through different control methods which could help in management of B. cucurbitae along with safe environment.

\section{Author's Contribution}

Muhammad Ibrahim Kubar conducted experiments and wrote the article. Fahad Nazir Khoso designed and supervised the entire work. Imran Khatri helped in techanical assistance. Niaz Hussain Khuhro provided necessary material and Arfan Ahmed Gilal helped in data analysis.

\section{Conflict of interests}

The authors have declared no conflict of interest.

\section{References}

Abro, Z.A., N. Baloch, N.H. Khuhro, W.A. Qazi and N.A. Saeed. 2017b. Population densities of melon fruit fly Bactrocera cucurbitae (Coquillett) in vegetables agro-ecosystem in District Hyderabad, Sindh, Pakistan. Sarhad J. Agric., 33(2): 331-337. https://doi.org/10.17582/ journal.sja/2017/33.2.331.337

Abro, Z.A., N. Baloch, N.H. Khuhro and W. Akbar. 2017a. Efficacy of Protein Bait Sprays in Controlling Melon Fruit Fly Bactrocera Cucurbitae (Coquillett) in Vegetable Agroecosystems Proc.Pak. Acad. Sci. B. Life Environ. Sci., 54(2): 111-115. https://doi.org/10.17582/ journal.sja/2017/33.2.331.337

Akhtaruzzaman, M., M.Z. Alam and M.M.A. Sardar. 2000. Efficiency of different bait sprays for suppressing fruit fly on cucumber. Bull. Inst. Trop. Agric., (Kyushu University), 23: 15-26.

Andleeb, S., M.S. Shahid and R. Mehmood. 2010. Biology of Parasitoid Aganaspis daci (Weld) (Hymenoptera: Eucoilidae). Pak. J. Sci. Indus. Res., 53(4): 201-204.

Bharathi, T.E., V.K.R. Sathiyanandam and P.M.M. David. 2004. Attractiveness of some food baits to the melon fruit fly, Bactrocera cucurbitae (Coq.) (Diptera: Tephritidae). Int. J. Trop. Inst. Sci., 24(2): 125-134. https://doi.org/10.1079/ IJT200412

Demeyer, M., M.P. Robertson, M.W. Mansell, S. Ekesi, K. Tsuruta, W.M. Waiko, J.F. Vayssieres and A.T. Peterson. 2010. Ecological niche and potential geographic distribution of the Invasive Fruit Fly Bactrocera invadens (Diptera, Tephritidae).Bull.Entomol.Res.,100(1):35-48. https://doi.org/10.1017/S0007485309006713

Dhillon, M.K., R. Singh, J.S. Naresh and H.C. Sharma. 2005. The melon fruit fly, Bactrocera cucurbitae: A review of its biology and management. J. Ins. Sci., 5: 40. available online: insectscience.org/5.40. https://doi. org/10.1093/jis/5.1.40

Hafiz, S., M.F. Nasir, A. Mohsin, M.S. Qureshi, A.M. Hamzah, S. Ghuffar, H. Anwar, U. Shoukat, Q. Ahmad and M.A. Aziz. 2020. Effect of plant extracts on egg deposition of fruit fly Bactrocera cucurbitae on bitter gourd. Int. J. Entmol. Res., 5(3): 116-119.

Haldhar, S.M., B.R. Choudhary, R. Bhargava and S.K. Sharma. 2014. Development of an organic Integrated Pest Management (IPM) Module against insect-pests of Muskmelon in arid region of Rajasthan, India. J. Exp. Biol. Agric. 
Sci., 2(1): 19-24.

Joomaye, A.N., N.S. Price and J.M. Stonehouse. 2000. Quarantine pest risk analysis of fruit flies in Indian Ocean: the of Bactrocera zonata. Proceedings of the Indian Ocean Commission regional fruit fly symposium. J. Econ. Entomol., 93(1): 81-87.

Khatiwada, B. and B.P. Pokhrel. 2004. Botanical pesticides 'Jholmal' for organic agriculture. Ecol. Cent. Tech. Bull., 1(2): 1-2.

Kumari, D.A., V. Suresh, M.H. Nayak, A.V.N. Lavanya and A. Mamatha. 2021. Evaluation of different pest management modules in bitter gourd. Int. J. Chem. Stud., 9(11): 587590. https://doi.org/10.22271/chemi.2021. v9.i1h.11293

Mahmood, T., S.I. Hussain, K.M. Khokhar and M.A. Hidayatullah. 2002. Studies on methyl eugenol as a sex attractant for fruit fly, Dacus zonatus (Saund) in relation to abiotic factors in peach orchard. Asian J. Plant Sci., 4: 401-402. https://doi.org/10.3923/ajps.2002.401.402

Muhammad, D.G., A. Muhammad, A.J. Muhammad, K.A. Muhammad and A. Fiaz. 2007. Co-administration of insecticides and butanone acetate for its efficacy against melon fruit flies, Bactrocera cucurbitae (Diptera: Tephritidae). Pak. J. Entomol., 29(2): 111-116.

Nath, P., 2007. Cucurbit everyone's crop, Proc. Of the $3^{\text {rd }}$ International Symposium on cucurbits, Sept 11-17, 2005, Townsville, Australia: Acta. Hortic., 731: 485-491. https://doi. org/10.17660/ActaHortic.2007.731.67

Papadopouls, N.T. and B.I. Katsoyanos. 2003. Field parasitism of ceratitus captita larvae by aganaspis daci in chios, Greece. Biocontrol., 48: 191-195.

Sarkar, R., S. Das, M.M. Kamal, K.S. Islam and M. Jahan.2017.Efficacy of management approaches against cucurbit fruit fly (Bactrocera cucurbitae Coquillett) of bitter gourd. Bangladesh J. Agric. Res., 42(4): 757-766. https://doi.org/10.3329/ bjar.v42i4.35803

Sarwar, M., M. Hamed, B. Rasool, M. Yousaf and M. Hussain. 2013. Host preference and performance of fruit flies Bactrocera zonata (Saunders) and Bactrocera cucurbitae (Coquillett) (Diptera: Tephritidae) for various fruits and vegetables. Int. J. Sci. Res. Environ.
Sci., 1(8): 188-194. https://doi.org/10.12983/ ijsres-2013-p188-194

Shah, S.M.M., N. Ahmad, M. Sarwar and M. Tofique. 2014. Rearing of Bactrocera zonata (Diptera: Tephritidae) for parasitoids production and managing techniques for fruit flies in mango orchards. Int. J. Trop. Inst. Sci., 34(S1): S108-S113. https://doi. org/10.1017/S1742758414000137

Shang, Q., N. Ling, X. Feng, X. Yang, P. Wu and J. Zou. 2014. Soil fertility and its significance to crop productivity and sustainability in typical agroecosystem: A summary of longterm fertilizer experiments in China. J. Plant Soil., 381: 13-23. https://doi.org/10.1007/ s11104-014-2089-6

Slavin, J.L. and B. Lloyd. 2012. Health benefits of fruits and vegetables. J. Adv. Nutr., 3(4): 506516. https://doi.org/10.3945/an.112.002154

Statistix, 2006. Statistix 8.1 user guide, version 1.0. Analytical Software, P.O Box 12185, Tallahassee FL 32317 USA. Copyright (C) 2006 by Analytical Software.

Uzair, A. and B. Unab. 2016. Impact of lure treatments against Bactrocera cucurbitae, Bactrocera dorsalis and Bactrocera zonata (Diptera: Tephritidae) in Peshawar, Pakistan. J. Entomol. Zool. Stud., 4(6): 729-732.

Vargas, R.I., J.D. Stark, M.H. Kido, H.M. Ketter and L.C. White. 2000. Methyl eugenol and cue-lure traps for suppression of male oriental fruit flies and melon flies (Diptera: Tephritidae) in Hawaii. J. Econ. Entomol., 93(1): 81-87. https://doi.org/10.1603/0022-0493-93.1.81

Weems, H.V.J. and J.B. Heppner. 2004. Melon fly, Bactrocera cucurbitae (Coq.) (Insecta: Diptera: Tephritidae). Florida department of agriculture and consumer services, division of plant industry, and T.R. Fasulo, University of Florida. University of Florida Pub., EENY-199. https:// doi.org/10.32473/edis-in356-2004

Weinberger, K. and C.A. Genova II.2005. Vegetable production in Bangladesh. commercialization and rural livelihoods. Tech. Bull. No. 33. AVRDC publication number 05-621. Shanhua, Taiwan: AVRDC-The World Vegetable Center. pp. 51. 